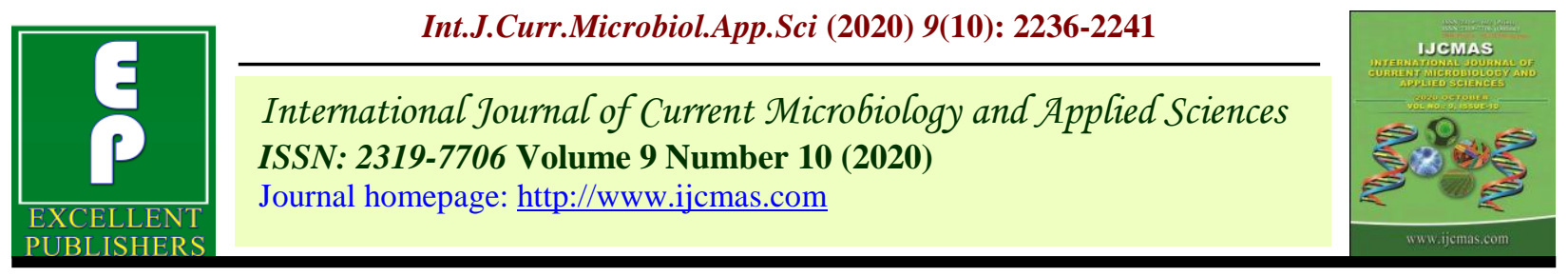

Review Article

https://doi.org/10.20546/ijcmas.2020.910.270

\title{
Humic Acid-A Critical Review
}

\author{
Swarnali Duary* \\ Department of Agronomy, Bidhan Chandra KrishiVidyalaya, Mohanpur, Nadia, \\ West Bengal, India \\ *Corresponding author
}

\section{A B S T R A C T}

Keywords

Humic acid, Soil organic material, Crop production

Article Info

Accepted:

17 September 2020

Available Online:

10 October 2020
Soil organic material is needed up to a satisfactory level for sustainable crop production and high productivity of crops over long periods. Humic Acid (HA), an organic matter, might help to overcome the production constraints of crops with its growth stimulating property. Humic acid is the major component of most of the organic fertilizers and the most active components of soil and compost. Humic acid mainly arises from chemical and biological degradation of plant and animal residues and by the synthetic activities of different micro-organisms. After enriches into the soil it facilitates fertilizer nutrients to reach their maximum potential in improving plant growth.

\section{Introduction}

One of the most disruptive human activities is high-external input agriculture which has been justified by the current economic paradigm due to high productivity and the need to feed a growing population and we are dangerously close to the edge of the planet resources and both hunger and food insecurity has increased (Olivares et al., 2017). Excessive use of non-renewable chemical fertilizers and pesticides risks agricultural sustainability through the deterioration of soil and water resources, environmental quality (Ekin et al., 2019).Humic acid is an important soil component that can improve nutrient availability and impact on other important chemical, biological, and physical properties of soils (Meganind et al., 2015). The ecological benefits of humic acids are diverse and represent profitable and effective solutions for environmental problems and preservation of the environment (Manal et al., 2016). HA particularly K-Humate has potential to be used as an effective conversation and management tool for sustainability of the soil environment (Gumus et al., 2015). In agricultural production system the widespread use of unsuitable and unsustainable production techniques has resulted in extensive deterioration of soil 
quality, reductions in soil organic matter content (Martinez-Blanco et al., 2011). With increase in human population the soil quality is threatened by intensive management of cultivable land and by urbanisation and soil degradation. Humic acid is an effective agent to use as a complement to synthetic or organic fertilizers and regular humic acid use will reduce the need for fertilization due to the soil's and plant's ability to make better use of it or fertilization can be eliminated entirely if sufficient organic material is present and the soil can become self-sustaining through microbial processes and humus production (Khaled et al., 2011). Even in small quantities humic acid affect growth of living organism by inhibiting or stimulating the growth and they are also capable of protecting living cells against the toxic action of natural and anthropogenic compounds (Tikhonov et al., 2010).

\section{Definition of humic acid}

Humic acid is known to be among the most bio-chemically active materials found in soil and are considered to be the most abundant naturally occurring organic molecules on earth and also described as being the "most important component of a healthy fertile soil" (Calvo, 2014). Humic acid term is used for the brown-black, polymeric, alkali-soluble acids found in soils, plants, sea-grasses, fungi, sediments, and terrestrial and marine waters (Susic et al., 2016). Humic acid is the main fraction of humic substances (HS) and it is the most active components of soil and compost organic matter (Ferrara et al., 2008). Humic acid is also a naturally-available substance in the soil and a bio product of organic matter decomposition, which is successfully used in cultivation of various crops (Ekin et al., 2019). Generally, humic acid is high in molecular weight, dark brown in colour and soluble in an alkali solution. Humic acids are comprising a large family of organic compounds with identical characteristics that are products of organic matter transformations by soil microorganisms (Roy et al., 2017). Humic Acids are an effective agent to use as a complement to synthetic or organic fertilisers (Khaled et al., 2011).

\section{Sources of humic acid}

Humic acids are generally formed in senescent plant matter so it is important that plant trash from harvested crops is returned to the soil (Susic et al., 2016). Low rank coal can be successfully used as a rich source of humic acids in agriculture (Huculak-Maczka et al., 2018). Some developing countries used huge amount of lignite coals in agriculture as a rich source of humic acids (Susic et al., 2016). Composition of humic acid are contains $51 \%$ to $57 \% \mathrm{C}, 4 \%$ to $6 \% \mathrm{~N}$ and $0.2 \%$ to $1 \% \mathrm{P}$ and other micronutrients in minute amounts (Waqas et al., 2014).

\section{Benefits of humic acid}

Some beneficial effects of humic acid are:1) Addition of organic matter to organicallydeficient soils 2) Improved nutrient uptake 3) Increased chlorophyll synthesis 3) Increase root vitality 5) Better seed germination 6) Increased fertilizer retention capacity 7) Stimulate beneficial microbial activity 8) Healthier plants and improved yields.

Humic acids are beneficial in freeing up nutrients in the soil so that they are become available to the plant as needed (Khaled et al., 2011). As the humic acid molecules are small, which "allows them to reach the plant plasma membrane, where they effectively influence the assimilation of nutrients" (Quilty, 2011). Humic acid also accumulates toxic heavy metals very efficiently (Sinha et al., 2011). HA can enhance nutrient availability and improve chemical, biological, and physical soil properties (Meganind et al., 2015). The 
direct and indirect beneficial effects of HA on plant growth and development are their effect on cell membranes which lead to the enhanced transport of minerals, improved protein synthesis, plant hormone-like activity, promoted photosynthesis, modified enzyme activities, solubility of micro-elements and macro-elements, reduction of active levels of toxic minerals and increased microbial populations (Hamideh et al., 2013).

\section{Effect of HA on crop production}

Foliar application of humic acid improve the plant growth, accumulated photosynthetic matters and biological yield of red bean (Mohajerani et al., 2016). Application of zinc and boron in accompanied with humic acid and compost can be an effective nutritional manipulation by fixing the recommended dose of NPK to successfully reduce the pest and disease incidence in rice-mustard cropping system (Roy et al., 2017). Waqas et al., (2014) concluded that humic acid application in all the three methods i.e., soil fertilization, foliar sprays and seed treatment significantly enhances grain yield and yield components of mungbean. Olk et al., (2013) observed that humic products results significant increases in grain yield of maize (Zea mays L.) and soybean (Glycine max (L.) Merr.). Soil application of humus increased the $\mathrm{N}$ uptake of wheat and foliar application of humic acid increased the uptake of $\mathrm{P}, \mathrm{K}$, $\mathrm{Mg}, \mathrm{Na}, \mathrm{Cu}$ and $\mathrm{Zn}$ (Asik et al., 2009).
Highest values of spike length, number of grains/spike, grains weight/spike and thousand grains weight as well as grain yield of wheat were obtained by foliar spraying with 2 litres of humic acid (Manal et al., 2016). Humic fertilizer not only increases the yield of wheat, but also wheat quality reflexed by high content of carbohydrate and protein content of grain wheat (Manal et al., 2016). Nardi et al., (2002) reported the beneficial effect of humic acid on plant growth to the increasing cell membrane, oxygen uptake, respiration and photosynthesis, nutrients uptake, root and cell elongation and ion transport. Treatments receiving HA in both soil or foliar application caused pronounced increases in plant height, number of branches and dry weight of shoot of soybean compared to the untreated ones(Mahmoud et al., 2011).

\section{Drawbacks of humic acid application}

The application of the very high dose of humic acid is less effective (Lee and Bartlett, 1976). The beneficial effects of humic acids have been cleared but excessive use of these chemicals might lead to the environmental pollution (Yigit et al., 2008). No effect from application of humic acid (Turan et al., 2011; Aydin et al., 2012; Liu et al., 2002) or even growth reduction (Van et al., 2010) also observed. Several studies have reported all outcomes in experiments: positive, negative and nil effects (Lodhi et al., 2013).

Table.1 Effect of humic acid on Fusarium root rot diseases

\begin{tabular}{|c|c|}
\hline $\begin{array}{c}\text { Humic acid treatments } \\
\text { (mg a.i. } \text { plant }^{\mathbf{1}} \text { ) }\end{array}$ & Disease incidence (\%) \\
\hline $\mathbf{0}$ & 30.4 \\
\hline $\mathbf{8 0}$ & 29.6 \\
\hline $\mathbf{1 6 0}$ & 30.8 \\
\hline $\mathbf{2 4 0}$ & 34.4 \\
\hline
\end{tabular}

(Source: Yigit et al., 2008) 
In conclusion, humic acid (HA) is a vital constituent and an intimate part of soil organic structure. Many scientists, agronomists and farmers used humic acid for improving soil conditions and plant growth. Humic acid can ameliorate negative soil properties, improve the plant growth and uptake of nutrients. The application doses of humic acid are important for taking benefit from it. It is best to apply humic acid or humic acid in little amount throughout the crop period than at a huge amount or at a time. It is very important that plant trash from harvested crops is returned to the soil.

\section{References}

Asik, B.B., Turan, M.A., Celik, H. and Katkat, A.V. 2009. Effects of humic substances on plant growth and mineral nutrients uptake of wheat (Triticum durum cv. Salihli) under conditions of salinity. Asian Journal of crop Science. 1(2): 8795.

Aydin, A., Kant, C. and Turan, M.2012.Humic acid application alleviates salinity stress of bean (Phaseolus vulgaris L.) plants, decreasing membrane leakage. African Journal Agricultural Research. 7:1073-1086.

Calvo, P., Nelson, L. and Kloepper, J.W. 2014. Agricultural uses of plant biostimulants. Plant and Soil. 383(1): 341.

Ekin, Z. 2019. Integrated use of humic acid and plant growth promoting rhizobacteria to ensure higher potato productivity in sustainable agriculture. Sustainability. 11(12):1-13.

Ferrara, G. and Brunetti, G. 2008. Influence of foliar applications of humic acids on yield and fruit quality of table grape cv. Italia. Journal International Science Vigne Vin. 42(2): 79-87.

Gumus, I. and Seker, C. 2015. Influence of humic acid applications on soil physicochemical properties. Solid Earth Discuss. 7: 2481-2500.

Hamideh, G., Samavat, S. and Ardebili, Z.O. 2013. The alleviating effects of humic substances on photosynthesis and yield of Plant ago ovate in salinity conditions. International Research Journal of Applied and Basic Sciences. 4(7): 1683-1686.

Huculak-Mączka, M., Hoffmann, J. and Hoffmann, K. 2018. Evaluation of the possibilities of using humic acids obtained from lignite in the production of commercial fertilizers. Journal of Soils Sediments. 18: 2868-2880.

Khaled, H. and Fawy, H.A. 2011. Effect of different levels of humic acids on the nutrient content, plant growth, and soil properties under conditions of salinity. Soil \& Water Research. 6(1): 21-29.

Lee, Y.S. and Bartlette, R.I. 1976. Stimulation of plant growth by humic substances. American Journal of soil Science.40: 876879.

Liu, C. and Cooper, R.J. 2002. Humic acid application does not improve salt tolerance of hydroponically grown creeping bentgrass. Journal American Society for Horticultural Science.127: 219-223.

Lodhi, A., Tahir, S., Iqbal, Z., Mahmood, A., Akhtar, M., Qureshi, T.M., Yaqub, M. and Naeem, A. 2013. Characterization of commercial humic acid samples and their impact on growth of fungi and plants. Soil Environment. 32: 63-70.

Mahmoud, M.M., Hassanein, A.H.A., Mansour, S.F. and Khalefa, A.M. 2011. Effect of soil and foliar application of humic acid on growth and productivity of soybean plants grown on a calcareous soil under different levels of mineral fertilizers. Journal Soil Science and Agricultural Engineering. 2(8): 881-890.

Manal, F.M., Thalooth, A.T., Amal, G., Ahmed, M.H. and Mohamed, M.H. 2016. Evaluation of the effect of chemical 
fertilizer and humic acid on yield and yield components of wheat plants (Triticum aestivum) grown under newly reclaimed sandy soil. International Journal of Chem Tech Research. 9(8): 154-161.

Martinez-Blanco, J., Munoz, P., Anton, A. and Rieradevall, J. 2011. Assesment of tomato Mediterranean production in openfilled and standard multi-tunnel greenhouse, with compost or mineral fertilizers, from an agricultural and environmental stand point. Journal of Cleaner Production. 19: 985-997.

Meganid, A.S., Hassan, S., Al-Zahrani, ELMetwally, M. and Selim. 2015. Effect of humic acid application on growth and chlorophyll contents of common bean plants (Phaseolus vulgaris L.) under salinity stress conditions. International Journal of Innovative Research in Science. 4(5): 2651-2660.

Mohajerani, S., Fazel, M.A., Madani, H., Lak, S. and Modhej, A. 2016.Effect of the foliar application of humic acid on red bean cultivars (Phaseolus vulgaris L.).Journal of Experimental Biology and Agricultural Sciences. 4(5):519-524.

Nardi, S., Pizzeghello, D., Muscolo, A. and Vianello, A. 2002. Physiological effects of humic substances on higher plants. Soil Biology and Biochemistry. 34(11): 15271536.

Olivares, F.L., Busato, J.G., M. dePaula, A., Aguiar, L.S.L.N.O. and Olivares, L.P.C. 2017. Plant growth promoting bacteria and humic substances: crop promotion and mechanisms of action. Chemical and Biological Technologies in Agriculture. 4:30.

Olk, D.C., Dinnes, D.L., Callaway, C. and Raske, M. 2013. On-farm evaluation of a humic product in Iowa (US) maize production. In: Xu J et al., (eds) Functions of natural organic matter in changing environment. Zhejiang University Press and Springer Science+ Business Media,
Dordrecht, pp 1047-1050.

Quilty, J. and Cattle, S. 2011. Use and understanding of organic amendments in Australian agriculture: a review. Soil Research. 49(1): 1-26.

Roy, D., Sarkar, S., Sardar, S. and Sengupta, K. 2017. Effect of nutrient management on the incidence of major insect and disease pests in rice-mustard cropping system. International journal of chemical studies. 5(6): 1408-1412.

Sinha, B. and Bhattacharyya, K. 2011. Retention and release isotherm of arsenic in arsenic humic/fulvic equilibrium study. Biology and Fertility of Soils. 47: 815822.

Susic, M. (2016). Replenishing humic acids in agricultural soils. Agronomy.6(4): 45.

Tikhonov, V.V., Yakushev, A.V., Zavgorodnyaya, Y.A., Byzov, B.A. and Demin, V.V. 2010. Effects of humic acids on the growth of bacteria. Soil biology. 3: 333-341.

Turan, M.A., Asik, B.B., Katkat, A.V. and Celik, H.2011.The effects of soil-applied humic substances to the dry weight and mineral nutrient uptake of maize plants under soil-salinity conditions. Notulae Botanicae Horti Agrobotanici ClujNapoca. 39:171-177.

Van, J.T. 2008. Effect of potassium humate on soil properties and growth of wheat. Master's Thesis, University of the Free State, Bloemfontein, South Africa.

Waqas, M., Ahmad, B., Arif, M., Munsif, F., Khan, A., Amin, M., Sang-MoKang, S.M., Yoon-HaKim, Y. and Lee, I. 2014. Evaluation of humic acid application methods for yield and yield components of mungbean. American Journal of Plant Sciences. 5: 2269-2276.

Yigit, F. and Dikilitas, M.2008.Effect of humic acid applications on the root-rot disease caused by Fusarium Spp. on tomato. Plant Pathology Journal. 7(2): 179-182. 


\section{How to cite this article:}

Swarnali Duary. 2020. Humic Acid-A Critical Review. Int.J.Curr.Microbiol.App.Sci. 9(10): 2236-2241. doi: https://doi.org/10.20546/ijcmas.2020.910.270 